\title{
Factors associated with failure of clinical screening among blood donors who have altered serological results in the Centro Regional de Hemoterapia de Ribeirão Preto
}

\author{
Oranice Ferreira ${ }^{1}$ \\ Afonso Dinis Costa Passos ${ }^{2}$ \\ ${ }^{1}$ Centro Regional de Hemoterapia de Ribeirão \\ Preto, Universidade de São Paulo - USP, \\ Ribeirão Preto, SP, Brazil \\ ${ }^{2}$ Faculdade de Medicina de Ribeirão Preto - \\ Universidade de São Paulo - USP, Ribeirão \\ Preto, SP, Brazil
}

Conflict-of-interest disclosure:

The authors declare no competing financial interest

Submitted: 10/6/2011

Accepted: 8/20/2012

Corresponding author:

Oranice Ferreira

Hemocentro de Ribeirão Preto

Rua Tenente Catão Roxo, 2501

14051-140 Ribeirão Preto, SP, Brazil

oranice@hemocentro.fmrp.usp.br

www.rbhh.org or www.scielo.br/rbhh

DOI: $10.5581 / 1516-8484.20120103$
Objective: This study aimed to investigate the frequency of positive results for hepatitis $B$ and $C, H I V$ and syphilis in blood donations at the Centro Regional de Hemoterapia de Ribeirão Preto, to describe donors with positive results according to some demographic and socioeconomic variables, to identify risk factors associated to these donors and the reasons that they were not detected during clinical screening.

Methods: A descriptive study was performed between July $1^{\text {st }} 2005$ and July $31^{\text {st }} 2006$ by interviewing 106 donors after medical consultations where they were informed of positive results for hepatitis $B$, hepatitis $C$, HIV or syphilis.

Results: There was a predominance of first-time donors, males, under 50-year olds, married individuals, from Ribeirão Preto, with elementary education, low economic status and of people who donated at the request of friends or relatives. Hepatitis $C$ was the most frequently detected infection (56.6\%), followed by hepatitis B (20.7\%), HIV (12.3\%) and syphilis (10.4\%). About $40 \%$ of donors had omitted risk factors for different reasons: because they trusted the results of serological tests, did not feel comfortable about talking of risk factors or did not consider them relevant. Other justifications were the duration of the interview, the interviewer was unskilled, embarrassment and doubts about confidentiality.

Conclusion: The results indicate the need for changes in the approach to clinical screening and a review of methods to attract and guide potential donors.

Keywords: AIDS serodiagnosis; Syphilis serodiagnosis; Hepatitis B; Hepatitis C; Blood donors; Blood banks; Blood safety

\section{Introduction}

Among the main diseases that can be transmitted by blood transfusions are viral hepatitis, acquired immune deficiency syndrome (AIDS) and syphilis. Despite being mandatory to test for such diseases/infections ${ }^{(1)}$, there is still a concern about donations in the immunological window period when serological tests are unable to detect infectious agents in the blood ${ }^{(2-5)}$.

Some resources are used to try to reduce this potential risk with one of the most important ones being clinical screening (CS). Despite this, people with high-risk behavior continue to donate blood which can compromise the safety of those who receive it. Doll et al., while studying the characteristics of the behavior of blood donors that were identified as HIV seropositive at the time of serological screening, observed that $27 \%$ were pressured to donate, $15 \%$ wanted to test for HIV and $10 \%$ thought the tests could identify all infected donors ${ }^{(6)}$. Lefrère et al., in a study of donors identified as HIV seropositive in Paris, found that most of them had associated risk factors and most, probably, omitted such information during the $\mathrm{CS}^{(7)}$. Gonçalez et al., researching donors at a large blood center in São Paulo, Brazil, identified that $7 \%$ of them were "test seekers". They concluded that this type of motivation, allied to the lack of understanding of the immunological window period, compromises transfusion safety ${ }^{(8)}$. Some authors report that individuals at high-risk for HIV infection do exams by donating blood as they believe they are more reliable than those performed at other laboratories ${ }^{(5,9)}$. Other authors observed that, contrary to what might be expected, not always are voluntary donors, considered altruistic, safer than replacement donors that are usually responding to friends or relatives' requests and may be pressured to donate ${ }^{(10)}$.

Considering the importance of the CS and the need for it to be constantly perfected, the investigation of donors with positive serological tests after the donation has great relevance. The aim of the present study, performed with blood donors that came to the Ribeirão Preto Blood Center, was to identify the frequency of donations with positive results for hepatitis B and C, HIV and syphilis, to characterize these donors according to some demographic and socioeconomic variables and to identify risk factors, as well as the causes for failing to detect them in the CS.

\section{Methods}

This is a descriptive study performed with donors that came for a medical appointment at the Ribeirão Preto Blood Center between July $1^{\text {st }} 2005$ and July $31^{\text {st }} 2006$, after the results of testing their donated blood were positive for one or more of the following: Elisa HBsAg, Elisa anti-HCV, Elisa anti-HIV or venereal disease research laboratory test (VDRL) with a titer greater than or equal to 1:8, or equal to 1:4 as well as being positive for FTA-ABS. 
The inclusion criterion of this study was a positive result for a blood sample collected after the medical appointment repeating the same tests that had positive results on the day of the donation. All exams were performed in the Blood Center's Serology Laboratory. According to the routine of the center, positive results for HIV are confirmed using the Western blot technique. For anti-HCV, positive tests are confirmed using commercial kits of a different brand than those used at the time of the donation. Positive tests for HBsAg and VDRL with a titer greater than 1:8 were repeated using different samples, but were not confirmed by other tests.

The participants were interviewed by the author of this study immediately after the medical appointment at which they became aware of the results of the tests repeated after the donation. The interview was performed using a customized data-collection instrument in a private room after informing the donor about the objectives of the study and acquiring informed consent. The instrument included questions about the participants' socioeconomic and demographic characteristics, their reasons, interests and knowledge related to donation, exams and the diseases/infections with positive tests; the risk factors to which the donor was submitted throughout his or her life that could be related to the disease/infection; and the clinical screening performed at the last donation including the actions of the screener and the donor's behavior. The participants' economic situation was defined by the Brazilian Economic Classification used by the Agência Brasileira de Empresas de Pesquisa (Brazilian Agency of Research Companies) ${ }^{(11)}$. All data were input into a database (Epi Data 3.0).

The project was approved by the Research Ethics Committee of Hospital das Clínicas da Faculdade de Medicina de Ribeirão Preto (HCFMRP) on 6/20/2005 (Process HCRP n ${ }^{\circ} 7884 / 2005$ ).

\section{Results}

Between July 1st and 31st 2006, 44,899 donor candidates were seen at the Blood Center, of which 37,233 (82.9\%) were considered apt in the CS and were submitted to serological screening. Four hundred and three donations were discarded in the serological screening $(1.1 \%)$ due to the infections of interest in this study with five samples presenting more than one positive or inconclusive test.

Table 1 shows the 165 positive and 243 inconclusive results, corresponding to $0.40 \%$ and $0.60 \%$ of the total donations, respectively. Positive anti-HCV and VDRL results were the most common with a predominance of HIV among the inconclusive (115/243 - 47.3\%) and anti-HCV among the positive results (79/165 - 47.9\%).

Table 1 - Distribution of the positive and inconclusive results in the serological screening exams according to the type of test

\begin{tabular}{|c|c|c|c|c|c|c|}
\hline \multirow{3}{*}{ Test } & \multicolumn{6}{|c|}{ Result } \\
\hline & \multicolumn{2}{|c|}{ Positive } & \multicolumn{2}{|c|}{ Inconclusive } & \multicolumn{2}{|c|}{ Total } \\
\hline & $\mathbf{n}$ & $\%$ & $\mathbf{n}$ & $\%$ & $\mathbf{n}$ & $\%$ \\
\hline HBsAg & 27 & 7 & 19 & 5 & 46 & 11 \\
\hline anti-HIV & 11 & 3 & 115 & 28 & 126 & 31 \\
\hline VDRL & 48 & 12 & 10 & 2 & 58 & 14 \\
\hline anti-HCV & 79 & 19 & 99 & 24 & 178 & 44 \\
\hline Total & 165 & 40 & 243 & 60 & 408 & 100 \\
\hline
\end{tabular}

Five donors had more than one positive result
Of the 403 donors deferred in the serological screening and called back to the Blood Center, 81 (20.1\%) did not return, 43 $(10.7 \%)$ had a medical indication to postpone collecting the sample to repeat the test, $178(44.2 \%)$ had negative results, $14(3.5 \%)$ had positive results but were not interviewed (two refused and 12 did not show up on the scheduled date) and 87 (21.6\%) had positive results in the second sample and were included in this study. Nineteen other individuals who had donated blood before July $1^{\text {st }}$ 2005, but who returned to the Blood Center during the study period and fulfilled the inclusion criteria were also added in this study. Table 2 demonstrates that, of the 106 participants, most were male, under 50 years old, married, from Ribeirão Preto and region, with low levels of schooling and belonging to the $\mathrm{C}$ economic class according to the Brazilian economic classification ${ }^{(11)}$.

Table 2 - Distribution of the participants according to the gender, age group, marital status, origin, schooling level and economic class

\begin{tabular}{|c|c|c|}
\hline Variable & n & $\%$ \\
\hline \multicolumn{3}{|l|}{ Gender } \\
\hline Male & 72 & 67.9 \\
\hline Female & 34 & 32.1 \\
\hline \multicolumn{3}{|l|}{ Age group (years) } \\
\hline $19-29$ & 35 & 33.0 \\
\hline $30-39$ & 26 & 24.5 \\
\hline $40-49$ & 34 & 32.1 \\
\hline $50-59$ & 7 & 6.6 \\
\hline $60-65$ & 4 & 3.8 \\
\hline \multicolumn{3}{|l|}{ Marital status } \\
\hline Married & 44 & 41.5 \\
\hline Single & 25 & 23.5 \\
\hline Widow/Widower & 4 & 3.8 \\
\hline Stable relationship & 20 & 18.9 \\
\hline Separated/Divorced & 13 & 12.3 \\
\hline \multicolumn{3}{|l|}{ Residence } \\
\hline Ribeirão Preto & 41 & 38.7 \\
\hline Ribeirão Preto region & 39 & 36.8 \\
\hline Other cities in São Paulo State & 20 & 18.9 \\
\hline Other states & 6 & 5.6 \\
\hline \multicolumn{3}{|l|}{ Schooling level } \\
\hline Incomplete elementary school & 28 & 26.4 \\
\hline Complete elementary school & 35 & 33.0 \\
\hline Incomplete high school & 12 & 11.3 \\
\hline Complete high school & 17 & 16.1 \\
\hline Incomplete higher education & 7 & 6.6 \\
\hline Complete higher education & 7 & 6.6 \\
\hline \multicolumn{3}{|l|}{ Economic class } \\
\hline $\mathrm{A}+\mathrm{B}$ & 26 & 24.5 \\
\hline $\mathrm{C}$ & 50 & 47.2 \\
\hline $\mathrm{D}$ & 30 & 28.3 \\
\hline Total & 106 & 100.0 \\
\hline
\end{tabular}

According to Table 3, 63 individuals (59.4\%) were first-time donors. From the total, 32 (30.2\%) donated spontaneously, 40 (37.7\%) at the request of a friend/family member, $12(11.3 \%)$ were motivated by a campaign and $22(20.8 \%)$ donated for other reasons. From this last group, 19 were invited by other donors that accompanied them 
and three came for other reasons. Regarding the positive serological screening results, there was predominance of hepatitis $\mathrm{C}(56.6 \%)$, followed by hepatitis B (20.7\%), syphilis (12.3\%) and HIV (10.4\%).

\begin{tabular}{lcc}
$\begin{array}{l}\text { Table } 3 \text { - Distribution of the participants according to the number of donations, } \\
\text { the reason for donating and positivity of the serological screening tests }\end{array}$ & $\mathbf{n}$ \\
\hline Variable & & \\
\hline Number of donations & 63 & 59.4 \\
$1^{\text {st }}$ time & 26 & 24.5 \\
2 to 3 & 17 & 16.1 \\
4 or more & & \\
Reason for donating & 32 & 30.2 \\
Spontaneous & 40 & 37.7 \\
Request from a friend/family member & 12 & 11.3 \\
Motivated by campaign & 22 & 20.8 \\
Others & & \\
Positive serological screening tests & 13 & 12.3 \\
Syphilis & 11 & 10.4 \\
HIV & 22 & 20.7 \\
Hepatitis B & 60 & 56.6 \\
Hepatitis C & 106 & 100.0 \\
Total & & \\
\hline
\end{tabular}

Table 4 shows the donors' opinion about how they were possibly infected taking into account the risks to which they were exposed: fifteen $(14.2 \%)$ had received blood transfusions, 5 (4.7\%) had taken injectable illegal drugs, $14(13.2 \%)$ had homosexual relations with other men, $8(7.5 \%)$ had piercing or tattoos without adequate anti-septic precautions, $52(49.1 \%)$ had unprotected heterosexual relations with high-risk individuals, 9 (8.5\%) had had accidental contact with blood or other biological materials and 17 (16.1\%) reported other potential means of contagion.

The great majority of the participants $(75.5 \%)$ demonstrated that they did not know the limitations of the serological testing and stated their absolute confidence in the results. What called our attention was that 15 donors $(14.2 \%)$ admitted that they had donated in order to obtain the results of the exams. From these, four (26.7\%) wanted to know about HIV, one $(6.7 \%)$ about HIV and syphilis, one (6.7\%) about hepatitis C and nine (60.0\%) about other exams (four intended to do a check-up, three wanted to know their blood type and two thought they could obtain information about other infectious diseases such as dengue and toxoplasmosis).

Of all the interviewees, $99(93.4 \%)$ stated that they were asked in the CS about high-risk situations, whilst four (3.8\%) did not remember and three $(2.8 \%)$ said they were not asked. Of the 106 participants, 41 (38.7\%) admitted omitting facts during the CS by six leaving out more than one fact. The omissions referred to problems related to partners, male homosexual relationships, the use of drugs, risky heterosexual relationships and health problems.

Specifically to the 41 donors that admitted having omitted facts in the interview, an analysis of the motivation for this attitude showed that $14(34.1 \%)$ thought the fact irrelevant, 15 (36.6\%) manifested absolute confidence in the exams and $19(46.3 \%)$ because they did not feel like talking about the facts. It is worth pointing out that 34 $(82.9 \%)$ stated that they omitted facts for other reasons besides those
Table 4 - Distribution of the participants according to their perception regarding potential means of contagion at some time during their lives that may have caused the infection to which he or she presented positive serological screening tests

\begin{tabular}{|c|c|c|}
\hline Means of contagion & $\mathbf{n}$ & $\%$ \\
\hline \multicolumn{3}{|l|}{ Blood transfusion } \\
\hline Yes & 15 & 14.2 \\
\hline No & 85 & 80.2 \\
\hline Do not know & 6 & 5.6 \\
\hline \multicolumn{3}{|l|}{ Injectable drugs } \\
\hline Yes & 5 & 4.7 \\
\hline No & 101 & 95.3 \\
\hline \multicolumn{3}{|l|}{ Man/man sexual relation } \\
\hline Yes & 14 & 13.2 \\
\hline No & 58 & 54.7 \\
\hline Does not apply (women) & 34 & 32.1 \\
\hline \multicolumn{3}{|l|}{ Piercing/tattoo } \\
\hline Yes & 8 & 7.5 \\
\hline No & 94 & 88.7 \\
\hline Do not know & 4 & 3.8 \\
\hline \multicolumn{3}{|c|}{ Risky heterosexual relationship } \\
\hline Yes & 52 & 49.1 \\
\hline No & 37 & 34.9 \\
\hline Do not know & 17 & 16.0 \\
\hline \multicolumn{3}{|c|}{ Accident with biological material } \\
\hline Yes & 9 & 8.5 \\
\hline No & 95 & 89.6 \\
\hline Do not know & 2 & 1.9 \\
\hline \multicolumn{3}{|l|}{ Others } \\
\hline Yes & 17 & 16.1 \\
\hline No & 54 & 50.9 \\
\hline Do not know & 35 & 33.0 \\
\hline Total & 106 & 100.0 \\
\hline
\end{tabular}

mentioned above, among which problems related to the length of the interview and the abilities of the screener, lack of confidence in the confidentiality/privacy of the interview, embarrassment of talking in front of accompanying people, they felt healthy, did not want to talk about intimate issues, they were not asked about their partners, they did not remember, they wanted to be referred for treatment and/or they just wanted the results of the exams.

\section{Discussion}

The study sample presented a profile similar to the general donor population of the blood center in relation to the gender (predominantly male), age group (most under 50 years old) and origin (predominantly from Ribeirão Preto and region) ${ }^{(12,13)}$. As to the schooling level, although 63 donors (59.4\%) stated having incomplete or complete elementary school and only five $(4.7 \%$ of the total) stated having less than one year of schooling, during the interviews it was observed that many were only capable of signing their names, needing help even to date the informed consent form, which was an embarrassing situation for some. This fact highlights the difficulties many certainly faced to read and assimilate the written information offered to them during 
the donation process, as well as to express their doubts and take advantage of the opportunity to clarify them.

Spanó, in a study of first-time donors at the Centro Regional de Hemoterapia de Ribeirão Preto, showed that $46 \%$ of individuals who received the informative material on the day of the donation reported that they did not read it or only read it partially; of these, $54.6 \%$ stated that they were not interested in doing so $^{(13)}$. The common lack of the habit of reading in our society is associated to the aforementioned difficulties, as well as to embarrassment that donors demonstrate in respect to their limitations and may explain the lack of interest in the educational material currently used and its apparent lack of efficacy.

The sample was mainly composed of first-time donors (59.4\%), whilst in the general blood center population this percentage is around $24 \%$ of donors considered apt in the CS. This data may be explained by the fact that the first-time donor is being submitted to the first serological screening and thus has a higher probability of presenting a positive result when compared to other donors ${ }^{(14)}$.

Most participants identified one or more risk situations that might have been responsible for their contagion, with the most frequent being high-risk heterosexual relationships (49.1\%). It is also worthwhile mentioning that no risk factor was detected for 28 participants $(26.4 \%$ of the total $)-21$ donors with hepatitis $\mathrm{C}$ (35\% of those positive for anti-HCV) and seven donors with hepatitis B (31.8\% of those positive for HBsAg). Similar findings have been observed by other authors regarding $\mathrm{HCV}^{(15-17)}$.

Although 15 participants (14.2\%) admitted that they donated blood just to obtain the results of the exams, only six (5.7\% of the total) wanted to know about diseases classically transmitted by transfusion (HIV, syphilis and hepatitis C). The percentage of donors seeking the results of the exams, especially HIV, varies in the literature, for example it is $2.8 \%$ in Norway ${ }^{(18)}$, $5.9 \%$ in Hong Kong ${ }^{(19)}$ and $7 \%$ in São Paulo, Brazil ${ }^{(8)}$. This is an extremely relevant issue and its solution represents a challenge for blood transfusion services. This has led to a few authors reporting that it is very difficult to separate test seekers from the rest of the donors ${ }^{(5)}$. While some believe educational measures can be effective in solving this problem, others show that even after having improved the donor's understanding about the immunological window, some resist changing their behavior ${ }^{(5,20)}$.

The interest in other exams, showed by nine individuals in the present study, reinforces the donors' degree of lack of information as to the need to be healthy to donate blood and can also reflect the difficulties faced in accessing the health system.

A high percentage of participants $(68.9 \%)$ revealed that they did not know about the existence of services that offer serological exams for free, and only $9.4 \%$ of them knew about testing and counseling centers. It is intriguing that a relatively old and already well-structured service is so little known by the population, especially taking into account that information on testing and counseling centers and their locations is available in the informative material provided by the Centro Regional de Hemoterapia de Ribeirão Preto. This fact should lead to a reflection on the need to develop more effective means of divulging these centers than those presently employed. The use of short videos capable of calling the donors' attention or even group or face-to-face counseling may be useful.
Articles in the literature report that a certain percentage of donors fail to reveal high-risk behavior in the CS that would have excluded them as donation candidates ${ }^{(21,22)}$. This percentage reached approximately $40 \%$ in the present study and was mainly associated to sexual promiscuity, problems related to sexual partners, male homosexual relationships and the use of drugs. An analysis of the reasons that led to this attitude revealed an array of reasons that deserve to be carefully considered by blood transfusion services in respect to both the donor and the interview itself. Among the issues reported by the donors were their discomfort to reveal intimate facts, their belief that the exams provide total safety, that is, all positive samples will be detected and the idea that some incidents in their past may not be relevant to the current donation. The belief of some donors that thought it would not be necessary to report the use of injectable drugs in the distant past, as for them the matter was closed, illustrates this last reason.

Another reason mentioned was the embarrassment that some candidates felt because they were accompanied by other donors. In these situations, some participants stated that they had omitted facts in the interview because of their fear that being discharged could cause a negative impression to those who had invited them to donate, a phenomenon that has already been described in the literature ${ }^{(14)}$. This finding signals a need to guide volunteers involved in recruiting other donors, as this practice is frequently used by blood transfusion services.

Among the reasons for omissions related to the interview process, one of the most commonly mentioned was the fact that the interviewer limited the questioning to a certain period, and so the participant did not to declare situations that had happened at other times. In some cases, the interviewees reported not being asked about their sexual partners' health or risk situations related to them. Others attributed the omission to a very fast and mechanical interview, the young age of interviewers and their lack of involvement in the process. Additionally, with the evolution of the technical standards throughout time, CS has become increasingly technical and with a growing number of questions, incorporating more detailed and stricter documentation focused on avoiding mistakes. These changes have lengthened the duration of the interview, which leads to the donor applying pressure in order to speed up the process. All these findings reinforce the need to intervene in the screening process, going through the adequate selection of screeners and their effective qualification, as well as through the development of approaches that contribute to reduce the donors' anxiety. Thus, it is important to reach an ideal relationship between human resources and the demand, including the stimulus to make an appointment with the consequent control of the donor flow at the service.

Moreover, it is worth pointing out that five donors that omitted facts in the CS stated that they did not trust the confidentiality of the interview. This fact calls attention to how important it is for the institution to make every effort to emphatically transmit their complete compliance with this legal obligation to donors.

Among the limitations in this investigation are the sample size, determined by the limitation in time to perform the present study, the low prevalence of positive serological markers, the high absenteeism of donors invited back to know the results of exams and the impossibility of performing confirmation tests for 
all serological markers. Nevertheless, the results point towards a worrisome situation and indicate the need for changes in the approach to donors in the CS, besides training the screeners and qualifying them to overcome the problems indicated in this study. In a special way, the results in this study also highlight the importance of an in-depth reassessment of the blood center's clientele guidance/awareness procedures, to adapt and increase the potential of the methods currently used.

\section{References}

1. Brasil. Ministério da Saúde. Portaria $\mathrm{n}^{\circ} 1.353$, de 13 de junho de 2011. Aprova o regulamento técnico de procedimentos hemoterápicos [Internet]. Brasília, Ministério da Saúde; 2011. [cited 2012 Jan 21]. Available from: http://www.hemominas.mg.gov.br/export/sites/default/ hemominas/menu/aInstituicao/legislacao/pt-ms-1353.pdf

2. Covas DT. Retrovírus. In: Zago, MA, Falcão, RP, Pasquini R, editores. Hematologia: fundamentos e prática. São Paulo: Atheneu; 2001. p.691-704.

3. van den Burg PJ, Vrielink H, Reesink HW. Donor selection: the exclusion of high risk donors? Vox Sang. 1998;74( Suppl 2):499-502.

4. Schreiber GB, Busch MP, Kleinman SH, Korelitz JJ. The risk of transfusion-transmitted viral infections. The Retrovirus Epidemiology Donor Study. N Engl J Med. 1996;334(26):1685-90. Comment in: N Engl J Med. 1996;334(26):1734-5; N Engl J Med. 1996;335(21):1609-10.

5. Almeida-Neto C, Mendrone-Jr A, Salles NA, Sabino EC. Risco residual da transmissão do vírus da imunodeficiência humana por transfusão de sangue e hemocomponentes no Brasil. Tend HIV/AIDS. 2010;5(3):5-8.

6. Doll LS, Petersen LR, White CR, Ward JW. Human immunodeficiency virus type 1-infected blood donors: behavioral characteristics and reasons for donation. The HIV Blood Donor Study Group. Transfusion. 1991;31(8):704-9.

7. Lefrère JJ, Elghouzzi MH, Salpetrier J, Duc A, Dupuy-Montbrun MC. Interviews of individuals diagnosed as anti-human immunodeficiency virus-positive through the screening of blood donations in the Paris area to 1994: reflections on the selection of blood donors. Transfusion. 1996;36(2):124-7.

8. Gonçalez T, Sabino E, Sales N, Chen YH, Chamone D, Busch M, et al . Human immunodeficiency virus test-seeking blood donors in large blood bank in São Paulo Brazil. Transfusion. 2010;50(8):1806-14.

9. Stosic B. Factors associated with HVI infection among blood donors. Rev Bras Hematol Hemoter. 2012;34(3):186-7.

10. de Almeida Neto C, Murphy EL, McFarland W, Junior AM, Chen S, Chamone DA, et al. Profile of blood donors with serologic tests reactive for the presence of syphilis in São Paulo, Brazil. Transfusion. 2009;49(2):330-6.

11. Associação Nacional de Empresas de Pesquisa (ANEP). Critério de Classificação Econômica Brasil. São Paulo: ANEP; 1997. [cited 2006 Sep 19]. Available from: http://www.abep.org/novo/FileGenerate. ashx ?id $=285$

12. Valente VB, Covas DT, Passos AD. Marcadores sorológicos das hepatites B e C em doadores de sangue do Hemocentro de Ribeirão Preto, SP. Rev Soc Bras Med Trop [Internet]. 2005 [cited 2006 Jun 12];38(6):488-92. Available from: http://www.scielo.br/pdf/rsbmt/v38n6/a08v38n6.pdf

13. Spano CM. Estudo de algumas etapas do processo de seleção dos primo doadores de sangue do Centro Regional de Hemoterapia de Ribeirão Preto, SP [dissertação]. Ribeirão Preto: Faculdade de Medicina de Ribeirão Preto, Universidade de São Paulo; 2004.

14. Zaller N, Nelson KE, Ness P, Wen G, Kewir T, Bai X, et al. Demographic characteristics and risks for transfusion-transmissible infection among blood donors in Xinjiang autonomous region, People's Republic of China. Transfusion. 2006;46(2):265-71.

15. Abdourakhmanov DT, Hasaev AS, Castro FJ, Guardia J. Epidemiological and clinical aspects of hepatitis C virus infection in the Russian Republic of Daghestan. Eur J Epidemiol. 1998;14(6):549-53.

16. Alavian SM, Gholami B, Masarrat S. Hepatitis C risk factors in Iranian volunteer blood donors: a case-control study. J Gastroenterol Hepatol. 2002;17(10):1092-7.

17. Centers for Disease Control and Prevention. National Center for HIV, STD \& TB Prevention. Viral hepatitis [Internet]. Atlanta: CDC; 2007 [cited 2007 January 8]. Available from: http://www.cdc. gov/hepatitis/index.htm

18. Stigum H, Bosnes V, Magnus P, Orjasaeter H. Risk behaviour among blood donors who give blood in order to be tested for the human immunodeficiency virus. Vox Sang. 2001;80(1):24-7.

19. Lau JT, Thomas J, Lin CK. HIV-related behaviours among voluntary blood donors in Hong Kong. AIDS Care. 2002;14(4):481-92.

20. Almeida Neto C, Mendrone A Jr, Salles NA, Chamone DA, Sabino EC. O papel do médico na redução do risco residual da transmissão do vírus da imunodeficiência humana (HIV) por transfusão de sangue e hemocomponentes. Diagn Tratamento [Internet]. 2009 [cited 2010 Jul 12];14(2):57-61. Available from: http://files.bvs.br/ upload/S/1413-9979/2009/v14n2/a0002.pdf

21. Williams AE, Thomson RA, Schreiber GB, Watanabe K, Bethel J, Lo A, et al. Estimates of infectious disease risk factors in US blood donors. Retrovirus Epidemiology Donor Study. JAMA. 1997;277(12):967-72. Comment in: JAMA. 1997;278(4):289.

22. Stigum H, Bosnes V, Orjasaeter H, Heier HE, Magnus P. Risk behavior in Norwegian blood donors. Transfusion. 2001;41(12):1480-5. 